\title{
EFFECTS OF FIRE SEVERITY ON HABITAT RECOVERY IN A MIXED GRASS PRAIRIE ECOSYSTEM
}

\author{
Laura E. Jardine \\ Adam K. Ryburn \\ Anthony J. Stancampiano \\ Department of Biology \\ Oklahoma City University \\ Oklahoma City, OK 73106 \\ ajstancampiano@okcu.edu
}

Key words: Wichita Mountains, disturbance interaction, herbivory, competition

\begin{abstract}
We assessed the recovery and current status of three mixed grass prairie sites $5 \mathrm{yr}$ post burn in the Wichita Mountains Wildlife Refuge, Indiahoma, Oklahoma. These sites represent three burn histories: moderate burn, severe burn, and unburned. We used a modified point-intercept method to sample 38 habitat variables at 280 points along three transects at each site. These data were subjected to principal components analysis to assess trends in habitat structure among the sites. The first three components explained $66.6 \%$ of the variation in the dataset. Component I represents a gradient from short forbs, lichen covered rocks, and minimal disturbance to areas of tall grasses and ungulate disturbance. Component II represents a gradient from tall forbs and water disturbance to areas with woody shrubs, short herbaceous litter, and graminoid and moss ground cover. Component III represents a gradient from areas with mid-level forbs, fecal matter and herbaceous litter ground cover to areas with tall grasses and bare ground. Projections of the burn treatment sites onto principal components I-III indicate that the moderate and unburned sites cluster closely on component I but are distinct along components II and III. We interpret our results as supporting a relationship between high severity fire and more complete nutrient cycling from accumulated litter, leading initially post fire to dense grass cover followed by increasing forb cover. This increase in forage density potentially alters the grazing patterns of large herbivores, which inflicts higher levels of disturbance. Conversely, the unburned and moderate burn sites had a greater diversity of herbaceous species at lower coverage densities, perhaps resulting from reestablshiment from surviving shoots and seeds.

\section{INTRODUCTION}

Prairie ecosystems are maintained primarily through disturbance, herbivory, and competition. Fire is the principal disturbance type and can be manipulated and controlled by humans, or it can have a completely uncontrolled influence on the landscape. Historically, fire has been perceived in a negative context as having a detrimental effect on livestock, timber, and

other human-desired resources, and has subsequently been suppressed (Bland et al. 1973; Archer 1989; Allen and Palmer 2011). This attitude has softened somewhat in recent years, and fire is commonly used as a range management tool in an attempt to maximize forage quality, remove nonpalatable tissues, and to control encroachment of woody species (Archer 1994; Raynor et al. 2015; Collins 2016). Controlled burns are typically undertaken
\end{abstract}


when winds are low and humidity is high. Perimeters are established, and, if conducted properly, specific areas are evenly burned in terms of both areal extent and fire severity (Gibson and Hulbert 1987; Rideout-Hanzak et al. 2011; Gill et al. 2013; Winter 2013). These types of fires allow researchers to conduct before and after studies regarding a variety of ecological effects (Collins and Calabrese 2012; Winter et al. 2013; Larson 2014). Studies such as these produce valuable information due, in part, to the ability of researchers to replicate them. However, there are limits imposed on the various treatments involved by the fact that they must be controlled. This includes variables such as areal extent, fire intensity, burned patch shapes, and nonrandom site selection. Wildfires, on the other hand, whether human caused or natural, more closely represent the environmental pressures under which communities have evolved. All human controls are lost, and fires take their natural course as determined by climatic conditions (e.g. drought), wind direction, wind speed, fuel volume and quality, time since last burn, and topography (Gibson and Hulbert 1987). For example, spring fires generally tend to increase above ground biomass production by a few dominant grass species. This results in low species richness and diversity of forbs as competition for light increases (Gibson and Hulbert 1987; Collins and Calabrese 2011; Winter et al. 2013). Lowland areas support increased grass biomass and lower species diversity than upland prairie. These lower areas tend to have more available nutrients and soil moisture. Upland areas tend to have lower quality soils and therefore less dense vegetation. This combination of biotic (fuel volume and quality) and abiotic (elevation and moisture) factors, in addition to other physical factors such as wind speed and direction, determine fire characteristics. Because studies following these natural events are initiated after the fact and as such cannot be replicated, sampling cannot be entirely randomized. Additionally, there are no pre-established controls available for before and after comparison (Wiens and Parker 1995).

In this study, we compared the recovery of plant communities, assessed by sampling horizontal and vertical habitat structure, subjected to different burn treatments five years after a wildfire (Ferguson fire) in the Special Use Area (SUA) of the Wichita Mountains Wildlife Refuge (WMWR) in Indiahoma, Oklahoma. The objective of this paper is to describe the broad gradients of variation in the physical structure of these mixed grass prairie communities.

\section{METHODS AND MATERIALS}

The Wichita Mountains Wildlife Refuge is located in Comanche County, Oklahoma (Figure 1). It covers 23,885 ha of the Central Great Plains ecoregion (Woods et al. 2005). The SUA covers 14,136 ha on roughly the northern $2 / 3$ of the refuge. It consists of low, rounded granite mountains permeated by mixed grass prairie.

Mesophytic forests border streams and xeric forests consisting mostly of blackjack oak (Quercus marilandica Münchh.), post oak (Q. stellata Wangenh.), and eastern red cedar (Juniperus virginiana L.) and occur on lower granite hills. The Ferguson fire started on 1 September 2011, approximately $900 \mathrm{~m}$ east of the WMWR Visitor Center. Southerly winds rapidly pushed the fire northward into the SUA where the landscape was subjected to an incinerating burn that resulted in no remaining living vegetation. As the fire moved northward, it completely jumped small pockets of the landscape leaving them unburned. After burning through the refuge and exiting the north boundary, a northerly wind shift occurred pushing the fire southwest and back onto the refuge. This wind-shifted leg of the fire was less intense than the initial blaze due to light precipitation and light winds resulting in a moderately burned 


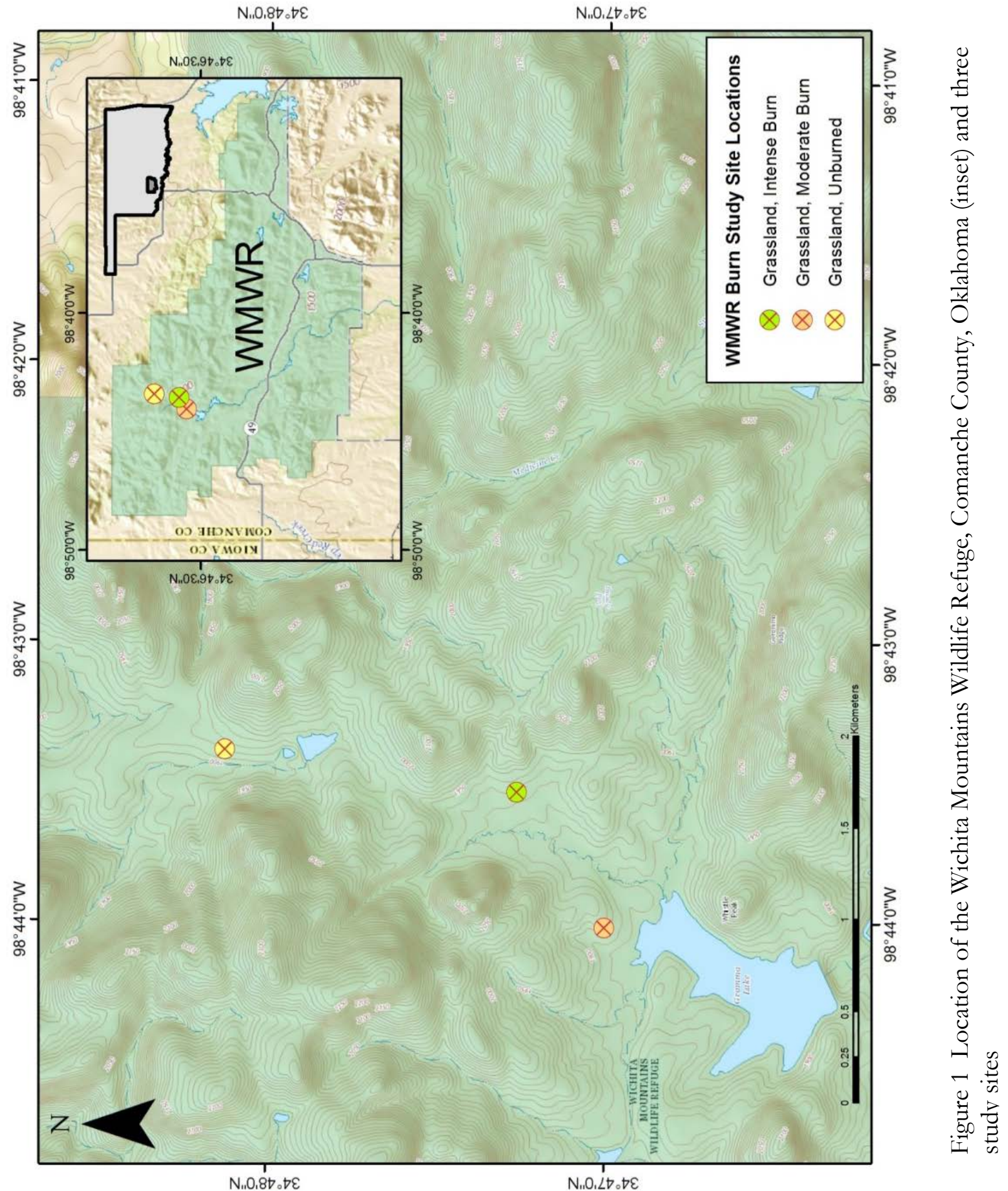




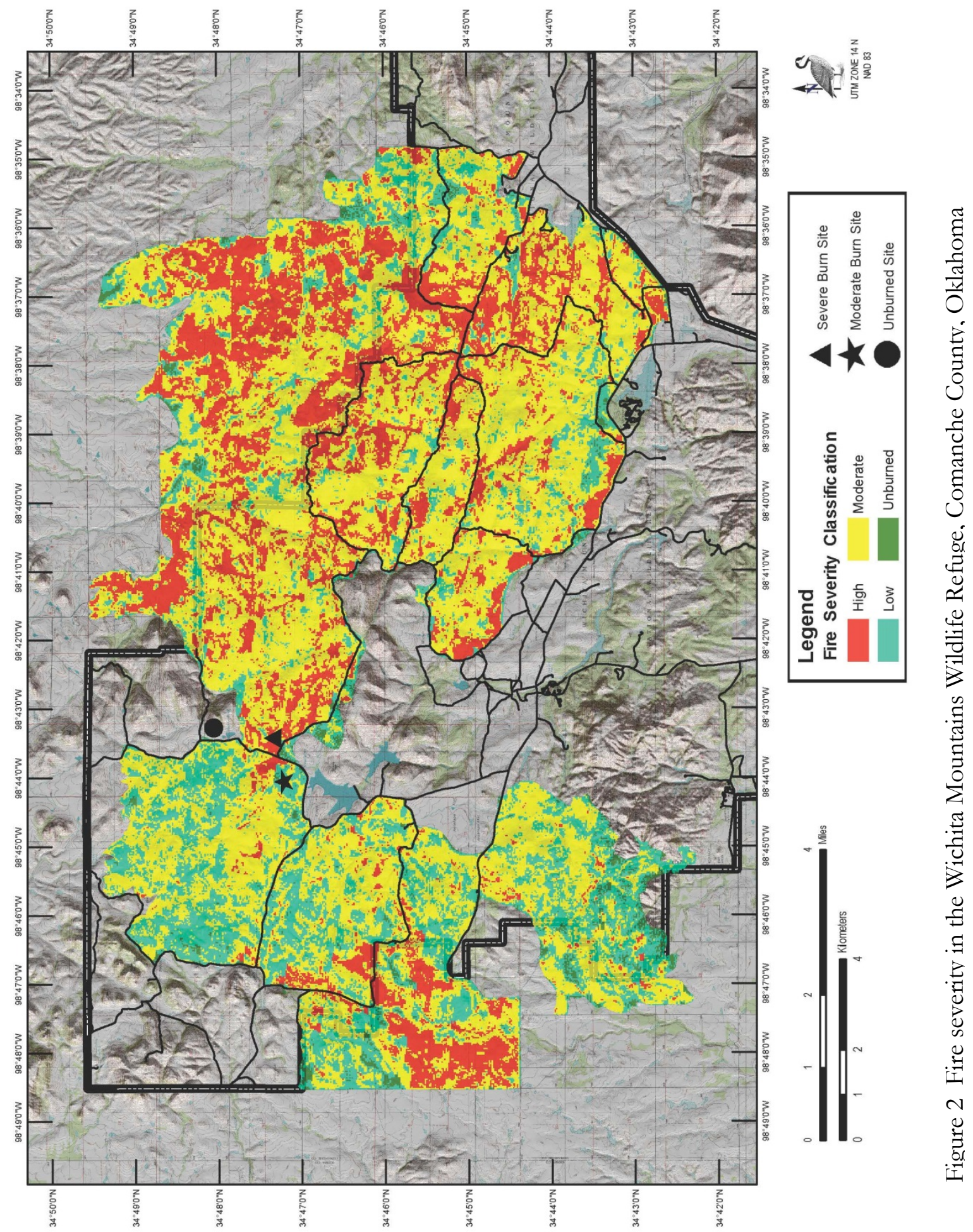


landscape where not all vegetation was destroyed. A total of 11,270 ha was burned on the WMWR. The Ferguson fire followed the hottest summer on record in Oklahoma since 1895 and moderate to extreme drought conditions in Comanche County since May 2010 (NOAA 2010).

We established three survey sites on 7 May 2016, one for each burn treatment (severe, moderate, and unburned), in mixed grass prairie of the SUA. Each site consisted of three $90 \mathrm{~m}$ transect arms extending from a center node (c-node) with one arm oriented in a north-south direction (0 to $\left.180^{\circ}\right)$. The other two arms extended from the c-node to the southeast $\left(135^{\circ}\right)$ and southwest $\left(225^{\circ}\right)$ for a linear total of 270 $\mathrm{m} /$ site. The maximum distance between sites was 2,351 $\mathrm{m}$ (unburned to moderate burn), and the minimum distance was 935 $\mathrm{m}$ (moderate to severe burn). The distance from the unburned to the severe burn site was 1,605 m (see Figure 1). Site elevations were within a $6.7 \mathrm{~m}$ range with the severe burn at $589.5 \mathrm{~m}$, moderate burn at $582.8 \mathrm{~m}$, and the unburned site at $585.5 \mathrm{~m}$. We sampled the physical structure at each site from 5-11 June 2016.

We assigned fire impact as unburned, moderate burn, and severe burn as determined by Stambaugh et al. (2015) (Figure 2). These classifications were derived through a combination of remote sensing, ground truthing, and modelling. Unburned indicates that the area after the fire was indistinguishable from pre-fire conditions. The moderate burn class represents a mixture of effects on the dominant vegetation with some patches of above ground cover completely removed while others show little or no change and low mortality of the dominant vegetation. High severity burn indicates complete consumption of the canopy (Stambaugh et al. 2015).

We used a modified point-intercept method to sample 38 habitat variables along each transect at each site. These variables included measures of ground disturbance, ground cover, and vertical cover (Table 1). To determine ground disturbance and cover, we passed a $3 \mathrm{~mm} \times 1 \mathrm{~m}$ rod vertically through the vegetation and onto the substrate at $0.5 \mathrm{~m}$ horizontal intervals along each transect. We recorded the ground disturbance and cover type at the point of contact. Ground disturbance type was determined by obvious alteration of ground cover, if any. At the same time, we determined vertical structure in decimeter intervals (1-10) by recording the interval at which any vertical cover contacted the rod. We sampled a total of 270 points at each site (Figure 3).

We used these data in a principalcomponents analysis (PCA) to assess patterns in habitat structure $5 \mathrm{yr}$ post fire. PCA is an unconstrained ordination method that is useful for visualizing broad patterns of covariation in a multivariate data set (Anderson and Willis 2003). All calculations were performed using NT-SYS (Rohlf 1998). We mean-centered the raw data and calculated correlations among the variables. We then projected the standardized data onto eigenvectors projected from the correlation matrix. 
Volume 16, December 2016

Table 1 Categories and description of variable codes used in point-intercept sampling of three burn treatments in the WMWR. Vertical cover (VC) is measured in decimeter categories.

\begin{tabular}{|c|c|c|c|}
\hline Category & $\begin{array}{l}\text { Variable } \\
\text { No. }\end{array}$ & Variable Code & Habitat Variable Description \\
\hline \multirow[t]{4}{*}{ Disturbance (Dist) } & 1 & $\mathrm{~N}$ & None \\
\hline & 2 & $\mathrm{UN}$ & Ungulate \\
\hline & 3 & W & Water \\
\hline & 4 & $\mathrm{H}$ & Human \\
\hline \multirow[t]{12}{*}{ Ground Cover (GC) } & 5 & CG & Crown Graminoid \\
\hline & 6 & $\mathrm{CF}$ & Crown Forb \\
\hline & 7 & $\mathrm{~L}$ & Lichen \\
\hline & 8 & $\mathrm{M}$ & Moss \\
\hline & 9 & $\mathrm{AC}$ & Algae/Cyanobacteria \\
\hline & 10 & $\mathrm{LH}$ & Litter Herbaceous \\
\hline & 11 & GR & Gravel $<7.5 \mathrm{~cm}$ \\
\hline & 12 & $\mathrm{CO}$ & Cobble $>7.5-25 \mathrm{~cm}$ \\
\hline & 13 & $\mathrm{BO}$ & Boulder $>25 \mathrm{~cm}$ \\
\hline & 14 & WA & Water \\
\hline & 15 & BG & Bare Ground \\
\hline & 16 & FM & Fecal Matter \\
\hline \multirow[t]{4}{*}{ Vertical Cover (VC) } & $17-20$ & LHV & Herbaceous Litter Vertical Hits \\
\hline & $21-28$ & FCG & Graminoid Foliage Cover Vertical Hits \\
\hline & $29-34$ & FCF & Forb Foliage Cover Vertical Hits \\
\hline & $35-38$ & FCS & Shrub Foliage Cover Vertical Hits \\
\hline
\end{tabular}




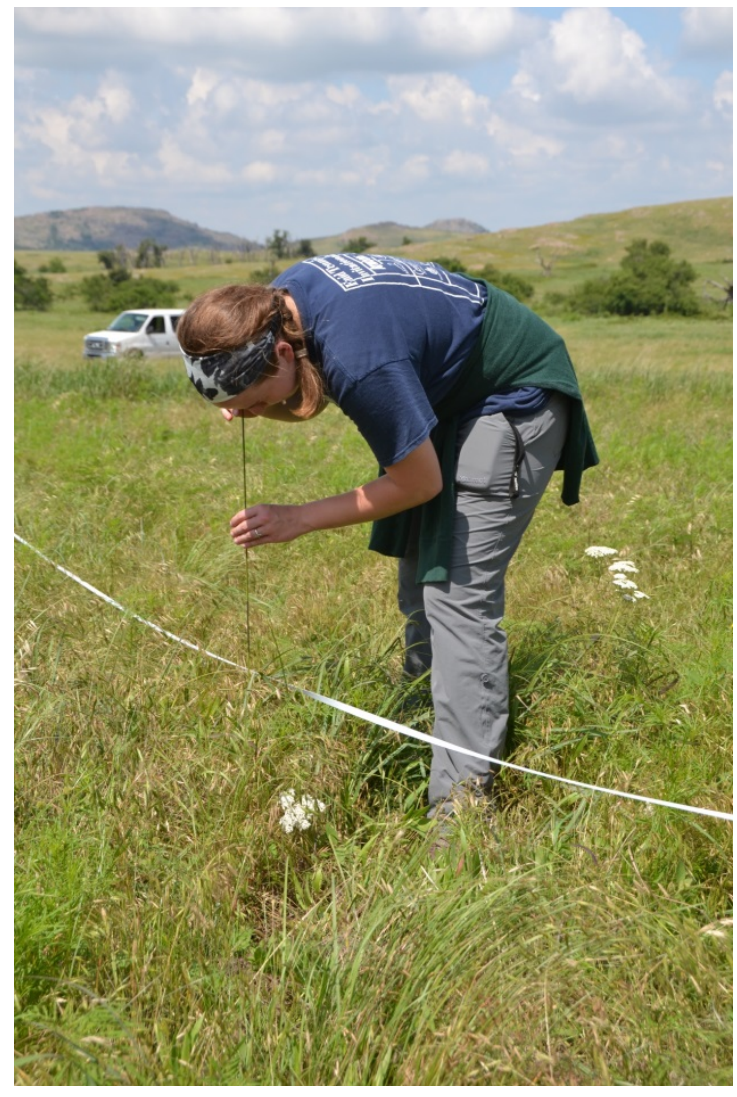

Figure 3 Author Laura Jardine sampling vertical structure at intense burn site in Wichita Mountains Wildlife Refuge

We surveyed the flora at each site by recording the presence of each species encountered (Table 2). Plant species identification followed the Flora of Oklahoma: Keys and Description (Tyrl et al. 2015).

\section{RESULTS}

Principal components analysis of 38 habitat variables produced three axes that accounted for $66.6 \%$ of the variation. Principal component I (PC I) explained $32.8 \%$, PC II $19.5 \%$, and PCIII $14.3 \%$ of the variation. Component I represents a gradient from short forbs, lichen covered cobble and boulders, and low disturbance to areas of tall grasses and ungulate disturbance (Table 3). Component II represents a gradient from tall forbs and water disturbance to areas with woody shrubs, herbaceous litter near the surface, and graminoid and moss ground cover. Component III represents a gradient from areas with mid-level forbs, fecal matter, and herbaceous litter ground cover to areas with tall grasses and bare ground cover.

Projections of the burn treatment sites onto PC I, PC II, and PC III indicate that the moderate and unburned sites cluster closely on PC I but are distinct along PC II and PC III (Figure 4). The severe burn has the highest positive loadings along PC I and is intermediate with respect to PC II (see Figure 4). The three transects for unburned and moderate burn sites cluster tightly within sites along PC III, but the two sites themselves are separated. The transects in the severe burn are widely separated along PC III.

The plant species composition of the three sites is as follows: unburned -40 species of 20 families; moderate burn - 40 species of 23 families; and severe burn -28 species of 13 families (see Table 2).

\section{DISCUSSION}

There have been few studies that inventory the flora of the Wichita Mountains (Eskew 1938; Osborn and Allan 1949; Buck 1977; Collins and Barber 1986; Carter et al. 2008). Other studies associate mixed grass prairie floristic components of the WMWR with specific mammal assemblages (Osborn and Allan 1949; Stancampiano and Caire 1995). Stancampiano and Schnell (2004) assessed small mammal distributions across nearby Fort Sill using, among others, vertical structure of vegetation. It appears that no studies have been published of the vertical structure or cover types on the WMWR prior to this study. Floristic composition across all sites is consistent with unpublished seasonal checklists and published floras of the area (Buck 1977; 
Volume 16, December 2016

Table 2 Plant community composition of three burn treatments in the Wichita Mountains Wildlife Refuge

\begin{tabular}{|c|c|c|c|c|c|}
\hline Species & Common name & Family & $\begin{array}{l}\text { Moderate } \\
\text { Burn }\end{array}$ & $\begin{array}{l}\text { Severe } \\
\text { Burn }\end{array}$ & $\begin{array}{l}\text { No } \\
\text { Burn }\end{array}$ \\
\hline Allium canadense & Canada garlic & Amaryllidaceae & $\mathrm{X}$ & $\mathrm{X}$ & $\mathrm{X}$ \\
\hline Daucus carota & Wild carrot & Apiaceae & $\mathrm{X}$ & & $\mathrm{X}$ \\
\hline Ptilimnium nuttallii & $\begin{array}{l}\text { Nuttall's } \\
\text { mockbishopweed }\end{array}$ & Apiaceae & & & $\mathrm{X}$ \\
\hline Asclepias viridis & Green antelope horn & Apocynaceae & $\mathrm{X}$ & $\mathrm{X}$ & $\mathrm{X}$ \\
\hline Yucca glauca & Small soapweed & Asparagaceae & $\mathrm{X}$ & & \\
\hline Achillea millefolium & Yarrow & Asteraceae & $\mathrm{X}$ & $\mathrm{X}$ & $\mathrm{X}$ \\
\hline Ambrosia psilostachya & Western ragweed & Asteraceae & $\mathrm{X}$ & $\mathrm{X}$ & $\mathrm{X}$ \\
\hline Artemisia ludoviciana & Louisiana sagewort & Asteraceae & $\mathrm{X}$ & $\mathrm{X}$ & \\
\hline Chaetopappa asteroides & Least daisy & Asteraceae & $\mathrm{X}$ & $\mathrm{X}$ & $\mathrm{X}$ \\
\hline Cirsium undulatum & Wavyleaf thistle & Asteraceae & $\mathrm{X}$ & & $\mathrm{X}$ \\
\hline Coreopsis lanceolata & Lanceleaf coreopsis & Asteraceae & $\mathrm{X}$ & & $\mathrm{X}$ \\
\hline Echinacea angustifolia & Black sampson & Asteraceae & $\mathrm{X}$ & & $\mathrm{X}$ \\
\hline Gaillardia pulchella & Indian blanket & Asteraceae & $\mathrm{X}$ & $\mathrm{X}$ & $\mathrm{X}$ \\
\hline Helenium amarum & Bitter sneezeweed & Asteraceae & $\mathrm{X}$ & & $\mathrm{X}$ \\
\hline Thelesperma filifolium & Plains greenthread & Asteraceae & & & $\mathrm{X}$ \\
\hline Vernonia baldwinii & Baldwin ironweed & Asteraceae & $\mathrm{X}$ & $\mathrm{X}$ & \\
\hline Lepidium virginicum & Virginia pepperrwort & Brassicaceae & $\mathrm{X}$ & $\mathrm{X}$ & $\mathrm{X}$ \\
\hline Paysonia auriculata & Earleaf bladderpod & Brassicaceae & & & $\mathrm{X}$ \\
\hline Echinocereus reichenbachii & Lace hedgehog cactus & Cactaceae & $\mathrm{X}$ & & \\
\hline $\begin{array}{l}\text { Opuntia bumifusa } \\
\text { var. humifusa }\end{array}$ & Prickly pear & Cactaceae & $\mathrm{X}$ & & $\mathrm{X}$ \\
\hline $\begin{array}{l}\text { Triodanis perfoliata } \\
\text { ssp. biflora }\end{array}$ & Small venus looking-glass & Campanulaceae & & & $\mathrm{X}$ \\
\hline Symphoricarpos orbiculatus & Buckberry & Caprifoliaceae & $\mathrm{X}$ & $\mathrm{X}$ & $\mathrm{X}$ \\
\hline Valerianella radiata & Cornsalad & Caprifoliaceae & & $\mathrm{X}$ & \\
\hline Tradescantia obiensis & Smoothstalk spiderwort & Commelinaceae & $\mathrm{X}$ & $\mathrm{X}$ & $\mathrm{X}$ \\
\hline Cuscuta cuspidata & Cusp dodder & Convolvulaceae & $\mathrm{X}$ & & \\
\hline Sedum nuttallii & Yellow stonecrop & Crassulaceae & $\mathrm{X}$ & & $\mathrm{X}$ \\
\hline Juniperus virginiana & Eastern red cedar & Cupressaceae & & & $\mathrm{X}$ \\
\hline Carex sp. & Sedge & Cyperaceae & & $\mathrm{X}$ & $\mathrm{X}$ \\
\hline Eleocharis montevidensis & Sand spikesedge & Cyperaceae & & $\mathrm{X}$ & $\mathrm{X}$ \\
\hline Amorpha canescens & Leadplant & Fabaceae & $\mathrm{X}$ & $\mathrm{X}$ & \\
\hline Baptisia australis & Blue wild indigo & Fabaceae & $\mathrm{X}$ & $\mathrm{X}$ & $\mathrm{X}$ \\
\hline Lespedeza virginica & Slender lespedeza & Fabaceae & & & $\mathrm{X}$ \\
\hline
\end{tabular}

Laura E. Jardine, Adam K. Ryburn, and Anthony J. Stancampiano 
Table 2 (continued)

\begin{tabular}{|c|c|c|c|c|c|}
\hline Species & Common name & Family & $\begin{array}{l}\text { Moderate } \\
\text { Burn }\end{array}$ & $\begin{array}{c}\text { Severe } \\
\text { Burn }\end{array}$ & $\begin{array}{l}\text { No } \\
\text { Burn }\end{array}$ \\
\hline Mimosa nuttallii & Catclaw sensitive brier & Fabaceae & $\mathrm{X}$ & & $\mathrm{X}$ \\
\hline Quercus marilandica & Blackjack oak & Fagaceae & & & $\mathrm{X}$ \\
\hline Quercus stellata & Post oak & Fagaceae & & & $\mathrm{X}$ \\
\hline Geranium carolinianum & Carolina geranium & Geraniaceae & $\mathrm{X}$ & $\mathrm{X}$ & \\
\hline Juncus sp. & Rush & Juncaceae & & & $\mathrm{X}$ \\
\hline Callirhoe involucrata & $\begin{array}{l}\text { Low poppymallow, } \\
\text { winecup }\end{array}$ & Malvaceae & $\mathrm{X}$ & & \\
\hline Oenothera glaucifolia & False guara & Onagraceae & $\mathrm{X}$ & $\mathrm{X}$ & $\mathrm{X}$ \\
\hline Oenothera suffrutescens & Scarlet beeblossom & Onagraceae & $\mathrm{X}$ & $\mathrm{X}$ & $\mathrm{X}$ \\
\hline $\begin{array}{l}\text { Castilleja purpurea } \\
\text { var. citrina }\end{array}$ & Citron paintbrush & Orobanchaceae & $\mathrm{X}$ & & \\
\hline Oxalis stricta & Sheep sorrel & Oxalidaceae & & & $\mathrm{X}$ \\
\hline Nuttallanthus texanus & Texas toadflax & Plantaginaceae & $\mathrm{X}$ & & $\mathrm{X}$ \\
\hline Plantago aristata & Bottlebrush plantain & Plantaginaceae & $\mathrm{X}$ & & $\mathrm{X}$ \\
\hline Plantago virginica & Paleseed plantain & Plantaginaceae & & $\mathrm{X}$ & \\
\hline Alopecurus carolinianus & Carolina foxtail & Poaceae & & & $\mathrm{X}$ \\
\hline Bromus japonicus & Japanese brome & Poaceae & & $\mathrm{X}$ & \\
\hline Bromus tectorum & Cheatgrass & Poaceae & $\mathrm{X}$ & $\mathrm{X}$ & $\mathrm{X}$ \\
\hline Dichanthelium oligosanthes & Scribner's panicum & Poaceae & & $\mathrm{X}$ & $\mathrm{X}$ \\
\hline Elymus repens & Quackgrass & Poaceae & $\mathrm{X}$ & & \\
\hline Hordeum pusillum & Little barley & Poaceae & & $\mathrm{X}$ & $\mathrm{X}$ \\
\hline Mnesithea cylindrica & Carolina jointtail grass & Poaceae & & $\mathrm{X}$ & \\
\hline Panicum virgatum & Switch grass & Poaceae & $\mathrm{X}$ & $\mathrm{X}$ & \\
\hline Schizachyrium scoparium & Little bluestem & Poaceae & & $\mathrm{X}$ & $\mathrm{X}$ \\
\hline Geum canadense & White avens & Rosaceae & $\mathrm{X}$ & & \\
\hline Prunus angustifolia & $\begin{array}{l}\text { Chickasaw plum } \\
\text { (sand plum) }\end{array}$ & Rosaceae & $\mathrm{X}$ & $\mathrm{X}$ & \\
\hline $\begin{array}{l}\text { Stenaria nigricans } \\
\text { var. nigricans }\end{array}$ & Narrowleaf bluet & Rubiaceae & $\mathrm{X}$ & & \\
\hline Selaginella perwiviana & Sheldon selaginella & Selaginellacea & $\mathrm{X}$ & & \\
\hline Solanum carolinense & Carolina groundcherry & Solanaceae & $\mathrm{X}$ & $\mathrm{X}$ & \\
\hline Glandularia canadensis & Rose verbena & Verbenaceae & $\mathrm{X}$ & & $\mathrm{X}$ \\
\hline
\end{tabular}


Volume 16, December 2016

Table 3 Summary of principal components analysis of 38 habitat variables for nine burn treatment sites

\begin{tabular}{|c|c|c|c|}
\hline Variable & PCI & PCII & PCIII \\
\hline VC-LHV 1 & 0.3276 & 0.5352 & 0.4793 \\
\hline VC-FCG 1 & -0.7487 & -0.4238 & 0.0202 \\
\hline VC-FCF 1 & -0.8446 & 0.1512 & -0.0202 \\
\hline VC-LHV 2 & -0.0607 & 0.3614 & 0.3851 \\
\hline VC-FCG 2 & -0.5746 & -0.3075 & 0.1936 \\
\hline VC-FCF 2 & -0.2223 & -0.0764 & -0.5285 \\
\hline VC-LHV 3 & -0.2355 & 0.3395 & -0.3065 \\
\hline VC-FCG 3 & 0.9065 & 0.3400 & -0.1269 \\
\hline VC-FCF 3 & 0.0143 & -0.0071 & -0.7783 \\
\hline VC-LHV 4 & -0.4187 & 0.4370 & 0.0380 \\
\hline VC-FCG 4 & 0.8107 & 0.3034 & 0.2569 \\
\hline VC-FCF 4 & 0.5395 & -0.5924 & -0.1209 \\
\hline VC-FCS 4 & -0.3047 & 0.7298 & -0.1569 \\
\hline VC-FCG 5 & 0.9105 & 0.0613 & 0.1999 \\
\hline VC-FCF 5 & 0.2135 & -0.5646 & -0.1058 \\
\hline VC-FCS 5 & -0.3047 & 0.7298 & -0.1569 \\
\hline VC-FCG 6 & 0.4988 & 0.6896 & 0.4904 \\
\hline VC-FCF 6 & 0.6083 & -0.3815 & -0.2211 \\
\hline VC-FCS 6 & -0.3047 & 0.7298 & -0.1569 \\
\hline VC-FCG 7 & 0.8268 & 0.1727 & 0.5080 \\
\hline VC-FCS 7 & -0.3047 & 0.7298 & -0.1569 \\
\hline VC-FCG 9 & 0.5711 & 0.3764 & 0.6516 \\
\hline
\end{tabular}


Table 3 (continued)

\begin{tabular}{lccc} 
Variable & PCI & PCII & PCIII \\
\hline Dist-N & -0.9067 & 0.2242 & 0.0895 \\
Dist-UN & 0.9394 & -0.1228 & -0.0914 \\
Dist-W & -0.6050 & -0.5713 & 0.4695 \\
Dist-H & 0.6083 & -0.3815 & -0.2211 \\
GC-CG & 0.1550 & 0.8001 & 0.0796 \\
GC-CF & -0.5041 & -0.1689 & 0.0406 \\
GC-L & -0.8289 & -0.0900 & 0.3338 \\
GC-M & -0.3086 & 0.8362 & -0.1531 \\
GC-AC & -0.2352 & 0.3120 & -0.3838 \\
GC-LH & 0.5002 & -0.2972 & -0.7984 \\
GC-GR & -0.2206 & 0.2877 & -0.4824 \\
GC-CO & -0.8596 & 0.0177 & 0.2127 \\
GC-BO & -0.8100 & -0.2332 & 0.4047 \\
GC-WA & -0.6050 & -0.5713 & 0.4695 \\
GC-BG & 0.3922 & -0.1612 & 0.7967 \\
\hline
\end{tabular}



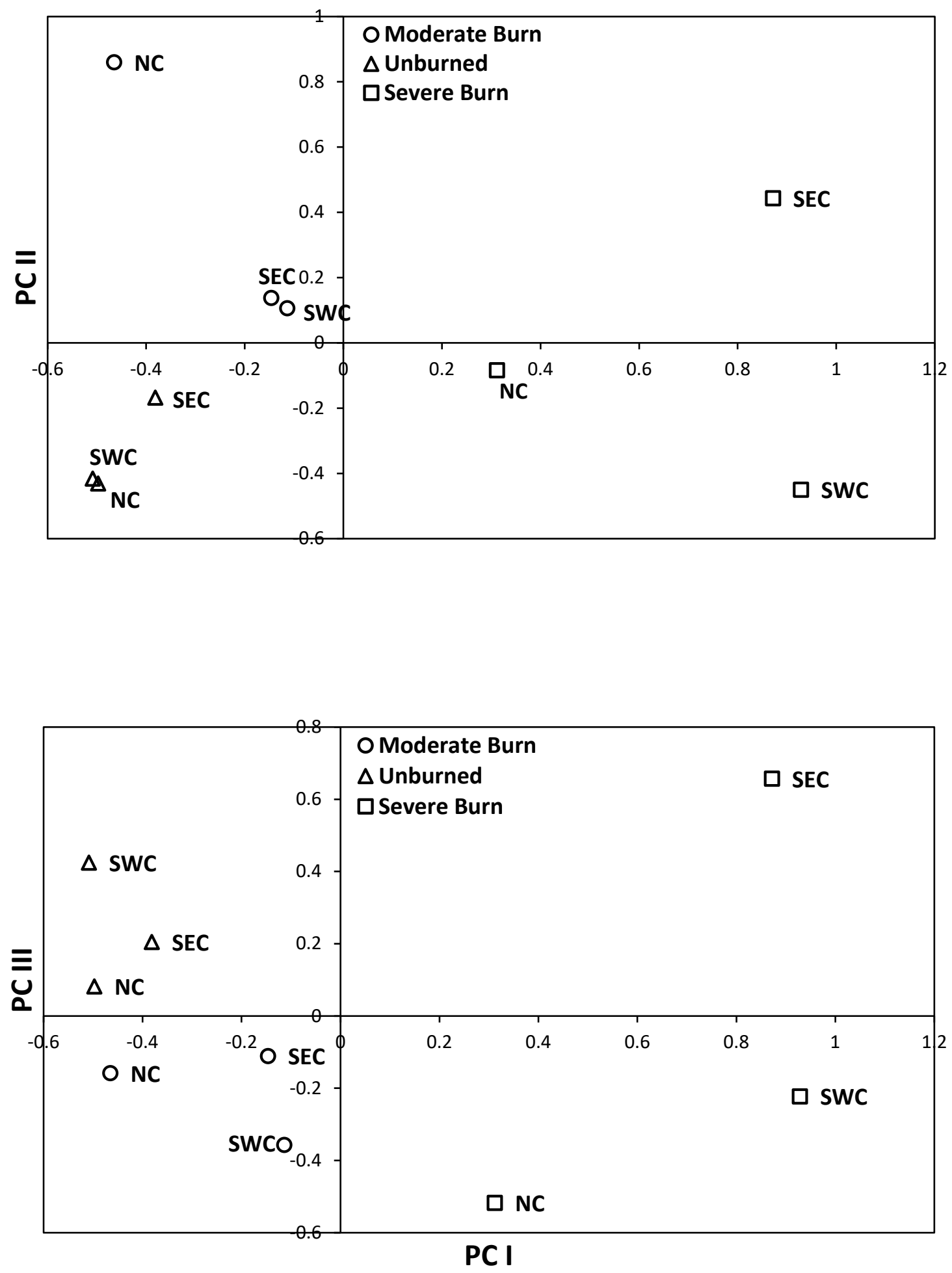

Figure 4 Projections of 3 study plots $(\mathrm{NC}=$ North to Central node; SEC $=$ Southeast to Central node; SWC=Southwest to Central node) based on 38 variables onto principal components I, II, and III in the Special Use Area of the Wichita Mountains Wildlife Area 
Carter et al. 2008). The unburned and moderate burn sites had higher spring species composition and cover of forbs when compared to the severe burn site which had higher cover of grasses.

The gradients produced by the PCA are consistent with other prairie fire studies with regard to plant species richness and the physical structure of the plant community (Gibson and Hulbert 1987; Collins and Calabrese 2012; Winter et al. 2013). Our study involved three study sites located within $2.5 \mathrm{~km}$ of each other, which reflects similar abiotic and biotic conditions.

Many studies measure differences in post fire prairie communities based on frequency of fires (Gibson and Hulbert 1987; Collins and Calabrese 2012; Winter et al. 2013). Using controlled fires in the tallgrass Konza Prairie, Gibson and Hulbert (1987) concluded that time since the last fire was the greatest determinant of prairie species composition. They also found that cover of grasses decreased over time, while cover of forbs and woody species increased. As in most controlled burns, fire severity was not taken into account. Their study took place prior to the reintroduction of bison to the Konza Prairie; therefore, there was no effect on vegetation from grazing. We made the assumption, a priori, that grazing by large herbivores (bison, elk, and longhorn cattle) was equal across all three burn treatments, post fire. Our analysis infers that large herbivores do indeed prefer the severe burn site forage at this point in recovery. We did, however, observe these large herbivores at all three sites. As indicated in studies of tallgrass ecosystems (Fuhlendorf and Engle 2004; Allred et al. 2011), it is possible that fire and grazing interact in landscapes to increase heterogeneity, as fire concentrates grazing activity to certain burned patches thereby reducing grazing in others. Our study supports the findings of many others in that fire severity also affects the recovery of vegetation, including not only composition but also its vertical and horizontal structure (Gibson and Hulbert 1987; Collins and Calabrese 2012; Winter et al. 2013). This follows the pattern of allogenic change due to fire fostering an increased probability of autogenic change (e.g., grazing) and its subsequent effects across the landscape.

\section{ACKNOWLEDGEMENTS}

We would like to thank the Wichita Mountains Wildlife Refuge and Dan McDonald for access to the Special Use Area and for logistical support. This study was supported, in part, by a 2016 CAIRS OCU Undergraduate Research Grant and the Beta Beta Beta Research Scholarship Fund. We thank the Dean's Office in the Petree College of Arts and Science and the Department of Biology at OCU for use of a field vehicle and financial support for field equipment and travel. We thank Matt White for creating the site location map (Figure 2). Finally, thanks to two reviewers for insightful comments and constructive suggestions.

\section{LITERATURE CITED}

Allen, M.S. and M.W. Palmer. 2011. Fire history of a prairie/forest boundary: More than 250 years of frequent fire in a North American tallgrass prairie. Journal of Vegetation Science 22:436-444.

Allred, B.W., S.D. Fuhlendorf, D.M. Engle, and R.D. Elmore. 2011. Ungulate preferences for burned patches reveal strength of fire-grazing interaction. Ecology and Evolution 1:132-144.

Anderson, M.J. and T.J. Willis. 2003. Canonical analysis of principal coordinates: A useful method of constrained ordination for ecology. Ecology 84:511-525.

Archer, S. 1989. Have southern Texas savannas been converted to woodlands in recent history? American Naturalist 134:545-561. 
Archer, S. 1994. Woody plant encroachment into southwestern grasslands and savannas: Rates, patterns and proximate causes. In: Vavra, M., W. Laycock, and R. Pieper (eds.). Ecological Implications of Livestock Herbivory in the West. Denver (CO): Society for Range Management. pp. 13-68.

Bland, R.E (chairman). 1973. Fire and the rural wildlands environment. In: America Burning. Library of Congress Card Number 73-600022. Washington (DC): National Commission on Fire Prevention and Control. pp. 93-103.

Buck, P. 1977. Vascular plants of the Wichita Mountains Wildlife Refuge. Wichita Mountains Wildlife Refuge informational brochure. Reprinted 2002. Oklahoma Native Plant Record 2:4-21.

Carter, K.A., P. Rodriguez, M.T. Dunn. 2008. An updated flora of the Wichita Mountains Wildlife Refuge. Oklahoma Native Plant Record 8:45-56.

Collins, S.L. 2016. Disturbance frequency and community stability in native tallgrass prairie. The American Naturalist 155:311-325.

Collins, S.L. and S.C. Barber. 1986. Effects of disturbance on diversity in mixedgrass prairie. Vegetatio 64:87-94.

Collins, S.L. and L.B. Calabrese. 2012. Effects of fire, grazing and topographic variation on vegetation structure in tallgrass prairie. Journal of $V$ egetation Science 23:563-575.

Eskew, C.T. 1938. The flowering plants of the Wichita Mountains Wildlife Refuge, Oklahoma. American Midland Naturalist 20:695-703.

Fuhlendorf, S.D. and D.M. Engle. 2004. Application of the fire-grazing interaction to restore shifting mosaic on tallgrass prairie. Journal of Applied Ecology 41:605-614.

Gibson, D.J. and L.C. Hulbert. 1987. Effects of fire, topography and year-toyear climatic variation on species composition in tallgrass prairie. Vegetatio 72:175-185.

Gill, A.M., S.L. Stephens, and G.J. Cary. 2013. The world "wildfire" problem. Ecological Applications 23:438-454.

Larson, D.M. 2014. Grassland fire and cattle grazing regulate reptile and amphibian assembly among patches. Environmental Management 54:1434-1444.

National Oceanic and Atmospheric Administration. 2010. National drought overview with map of Palmer Index drought conditions. https://www.ncdc.noaa.gov/sotc/drou ght $/ 201005$.

Osborn, B. and P.F. Allan. 1949. Vegetation of an abandoned prairie dog town in tall-grass prairie. Ecology 30:322-332.

Rideout-Hanzak, S., D.B. Wester, C.M. Britton, and H. Whitlaw. 2011. Biomass not linked to perennial grass mortality following severe wildfire in the southern high plains. Rangeland Ecology and Management 64:47-55.

Raynor, E.R., A. Joern, and J.M. Briggs. 2015. Bison foraging responds to fire frequency in nutritionally heterogeneous grassland. Ecology 96: 1586-1597.

Rohlf, F.J. 1998. NTSYSpc Numerical Taxonomy and Multivariate Analysis System. Version 2.0. Setauket (NY): Exeter Software.

Stambaugh, M.C., L.D. Hammer, and R. Godfrey. 2015. Performance of burnseverity metrics and classification in oak woodlands and grasslands. Remote Sensing 7:10501-10522.

Stancampiano, A.J. and W. Caire. 1995. Food habits of Peromyscus and Reithrodontomys in the Wichita Mountains Wildlife Refuge, Oklahoma. Proceedings Oklahoma Academy of Science 75:45-49.

Stancampiano, A.J. and G.D. Schnell. 2004. Microhabitat affinities of small mammals in southwestern Oklahoma. Journal of Mammalogy 85:948-958.

Tyrl, R.J., S.C. Barber, P. Buck, W.J. Elisens, J.R. Estes, P. Folley, L.K. Magrath, C.L.

Laura E. Jardine, Adam K. Ryburn, and Anthony J. Stancampiano 
Murray, A.K. Ryburn, B.A. Smith, C.E.S. Taylor, R.A. Thompson, J.B.

Walker, and L.E. Watson. 2015. Flora of

Oklahoma: Keys and Descriptions.

Oklahoma City (OK): Flora Oklahoma Inc.

Wiens, J.A. and K.R. Parker. 1995.

Analyzing the effects of accidental environmental impacts: Approaches and assumptions. Ecological Applications 5:1069-1083.

Winter, S.L., K.R. Hickman, C.L. Goad, S.D. Fuhlendorf, and M.S. Gregory. 2013. Seasonal fires, bison grazing, and the tallgrass prairie forb Arnoglossum plantagineum Raf. Natural Areas Journal 33:327-338.

Woods, A.J., J.M. Omernik, D.R. Butler, J.G. Ford, J.E. Henley, B.W. Hoagland, D.S. Arndt, and B.C. Moran. 2005. Ecoregions of Oklahoma (color poster with map, descriptive text, summary tables, and photographs) (map scale 1:1,250,000). Reston (VA): U.S.

Geological Survey. https://www.ncdc.noaa.gov/sotc/drou ght $/ 201005$. 